\title{
The chess players
}

\section{An unusual move.}

\section{Dan Gollub}

Advances in biomedical technology had not been in the forefront of Paul's consciousness when he entered the spacious living room of Stacy Ashland's home. Hed been wondering if he might find a girlfriend at her party. The odds, he knew, were against it. He was struggling to earn a living as a chess player, and the other guests at her party were likely to have a higher status in society. And anyway, his introverted personality and an overall lack of experience in relationships tended to thwart his chances of romance. But all such thoughts vanished from his mind when he saw a woman present who'd been much in the news lately. Rather, she and Jarvis McKnight together had been featured in newscasts, interviews and other media presentations. In the centre of the room, surrounded by a dozen or so friends and admirers, was Lena Adrian, with Jarvis's head transplanted onto her right shoulder. "Phenomenal breakthrough," a popular newscaster had said.

Stacy was amid the partygoers surrounding Lena and Jarvis, and she saw Paul and waved at him to come over. "Jarvis," she said in her extravagant socialite's voice, "this is the chess player I mentioned to you. He's been teaching chess to my son the past three months."

Jarvis's head nodded sombrely. "Chess has become more important to me recently."

He had a deep voice, Paul noted. The transplantation hadn't changed that aspect of his physiology.

"I'm sure the two of you will get along fine," Stacy commanded. She joined a nearby group of people and, as the hostess, was instantly welcomed into the conversation.

"Chess has an addictive side to it," Paul said. He saw that Lena was talking with a slim, long-legged man with a tattoo of a soccer ball on his arm. "Sometimes that's good, I suppose. And sometimes I lie awake after chess tournaments thinking about the moves I should have played differently."

Jarvis chuckled. Then a shadow crossed over his face. "Lena's not likely to sit through chess tournaments. But having someone such as you visit could be suitable for her."

Lena heard her name mentioned and turned to Paul. "He's a chess player," Jarvis said.
Lena's green eyes appraised Paul. She was about his age, he guessed. He remembered what the media had reported regarding her. She'd been in the foster-care system, had got a scholarship to college, had been majoring in theatre when the famed neuroscientist Jarvis McKnight had developed the massive staph infection that overwhelmed his bodily systems, and had volunteered for the transplant surgery that enabled the scientist to survive.

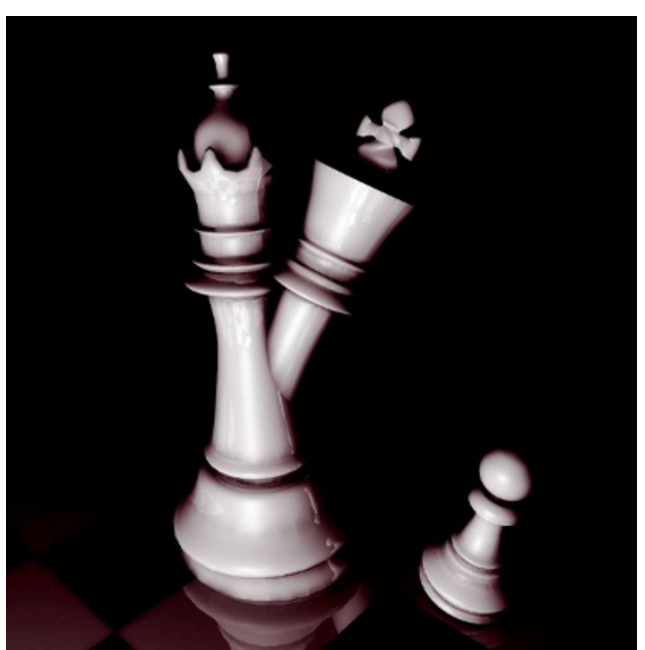

"There should be more to life than chess," Paul said. "I've been trying to become a poet."

"Tinkle tinkle little star," Lena said.

He wondered if she'd deliberately got the words wrong. "But I'll probably need a reliable career," he continued.

A complex expression flitted across her face. Was it a mixture of embarrassment and defiance? "We do what we must," she said. She turned back to the man she'd been chatting with.

Paul and Jarvis looked at each other.

"Yes," Jarvis said. "We do indeed do what we must."

Paul wanted to say to him, I've been on the fringes too. We have that bond between us. But he was silent.

"My research goals were too important," Jarvis said. "I couldn't let them die with me. And now I have a new goal. Can the brain be preserved against ageing if the host body that supports it is young and healthy? Perhaps cannulas bored through the skull into the brain can deliver a nourishing mixture of nutrients and antioxidants.

"And in fact why stop there?" Jarvis continued. "Those same tubes could deliver stimulants, which could improve the mind's talents. Perhaps with such injections you could become one of the top chess players. Or would you rather become obsessed with writing poetry?"

The choice hadn't occurred to Paul as one he might have to make.

"A few volunteers such as yourself could change the world," Jarvis said. "Maybe."

Before Paul got a chance to reply, a woman rushed up. "I've so wanted to meet you," she said in a gushing voice as she held out her hand to Jarvis. Then, realizing she'd committed a social blunder, she put her hand down and blushed.

"I'd shake your hand if I could," Jarvis said in a kindly tone.

"I've admired your courage, your commitment, your dedication to your ideals," she said.

"I think of it as desperation, instead," Jarvis said. "But thank you."

The woman retreated.

"We humans have our backs against the wall," Jarvis said quietly. "Perhaps some people don't realize that yet."

Paul didn't know what to say. Then he decided to make a jesting comment. "I'll cry if you say things like that."

Jarvis said simply, "I've cried, too."

Then he suddenly affixed his eyes on Paul's. "Would you like to have tubes drilled into your brain? Would you like new biochemical substrates that could give you a greatly expanded repertoire of abilities?"

At that point Lena turned her head toward Jarvis. Paul saw her companion had vanished. "I think you might be seeing more of Roberto," she said to Jarvis. Then she spoke to Paul. "Jarvis and I have an understanding. He doesn't expect me to be celibate. We discussed this before the operation."

"I'll bite it off if I get the chance," Jarvis said.

She laughed nervously. "Jarvis has an exquisite sense of humour. The two of us might go far together. I've been wondering if, in time, we might run for president. He with his intellect and I with my theatrical skills ... What great leadership we could provide."

All in all, Paul decided later, it had been an interesting evening.

Then he realized he hadn't answered Jarvis's question.

Dan Gollub is a psychologist. He had a story published in Writers Of The Future, Volume $X$. He has an original approach to dream interpretation which can be found at thenakedscientists.com. 